\title{
A peptide mimic of the chemotaxis inhibitory protein of Staphylococcus aureus: towards the development of novel anti-inflammatory compounds
}

\author{
Anton Bunschoten · Johannes H. Ippel • John A. W. Kruijtzer · Louris Feitsma • \\ Carla J. C. de Haas • Rob M. J. Liskamp • Johan Kemmink
}

Received: 17 May 2010/Accepted: 19 July 2010/Published online: 4 August 2010

(C) The Author(s) 2010. This article is published with open access at Springerlink.com

\begin{abstract}
Complement factor C5a is one of the most powerful pro-inflammatory agents involved in recruitment of leukocytes, activation of phagocytes and other inflammatory responses. C5a triggers inflammatory responses by binding to its G-protein-coupled C5a-receptor (C5aR). Excessive or erroneous activation of the $\mathrm{C} 5 \mathrm{aR}$ has been implicated in numerous inflammatory diseases. The C5aR is therefore a key target in the development of specific antiinflammatory compounds. A very potent natural inhibitor of the C5aR is the 121-residue chemotaxis inhibitory protein of Staphylococcus aureus (CHIPS). Although CHIPS effectively blocks $\mathrm{C} 5 \mathrm{aR}$ activation by binding tightly to its extra-cellular $\mathrm{N}$ terminus, it is not suitable as a potential anti-inflammatory drug due to its immunogenic properties. As a first step in the development of an improved CHIPS mimic, we designed and synthesized a substantially shorter 50-residue adapted peptide, designated CHOPS. This peptide included all residues important for receptor binding as based on the recent structure of CHIPS in complex with the C5aR $\mathrm{N}$ terminus. Using isothermal titration calorimetry we demonstrate that CHOPS has micromolar affinity
\end{abstract}

Electronic supplementary material The online version of this article (doi:10.1007/s00726-010-0711-3) contains supplementary material, which is available to authorized users.

A. Bunschoten · J. H. Ippel · J. A. W. Kruijtzer - L. Feitsma .

R. M. J. Liskamp · J. Kemmink ( $₫)$

Department of Medicinal Chemistry and Chemical Biology,

Utrecht University, Sorbonnelaan 16, 3584 CA Utrecht,

The Netherlands

e-mail: j.kemmink@uu.nl

C. J. C. de Haas

Medical Microbiology, University Medical Centre Utrecht,

Heidelberglaan 100, 3584 CX Utrecht, The Netherlands for a model peptide comprising residues $7-28$ of the C5aR $\mathrm{N}$ terminus including two $O$-sulfated tyrosine residues at positions 11 and 14. CD and NMR spectroscopy showed that CHOPS is unstructured free in solution. Upon addition of the doubly sulfated model peptide, however, the NMR and CD spectra reveal the formation of structural elements in CHOPS reminiscent of native CHIPS.

Keywords C5a receptor - CHIPS - Inflammation · Anaphylatoxin

\section{Introduction}

As part of the host defense system, the human complement cascade initiates inflammatory responses directed against invading infectious microorganisms, injury and other threatening conditions (Lee et al. 2008). Complement factor $\mathrm{C} 5 \mathrm{a}$ is the most powerful pro-inflammatory agent generated during complement activation. C5a interacts with the membrane associated G-protein-coupled C5a receptor $(\mathrm{C} 5 \mathrm{aR})$ resulting in chemotaxis of specific white blood cells, activation of phagocytes, release of granulebased enzymes, and the generation of oxidants (Guo and Ward 2005). C5a is a 74-residue glycoprotein comprising a bundle of four anti-parallel $\alpha$-helices stabilized by three disulfide bonds (PDB ID code: 1KJS). Binding and activation of the C5aR by $\mathrm{C} 5 \mathrm{a}$ is considered a two-step process, in which residues in the region between 12 and 46 of C5a bind to a primary binding site located in the extra-cellular $N$ terminus of the C5aR. Subsequently the C-terminal portion of C5a (residues 69-74) binds to the C5aR activation domain located inside the receptor core (Chen et al. 1998; Gerber et al. 2001). Together these two binding sites provide the complex of $\mathrm{C} 5 \mathrm{a}$ and the $\mathrm{C} 5 \mathrm{aR}$ 


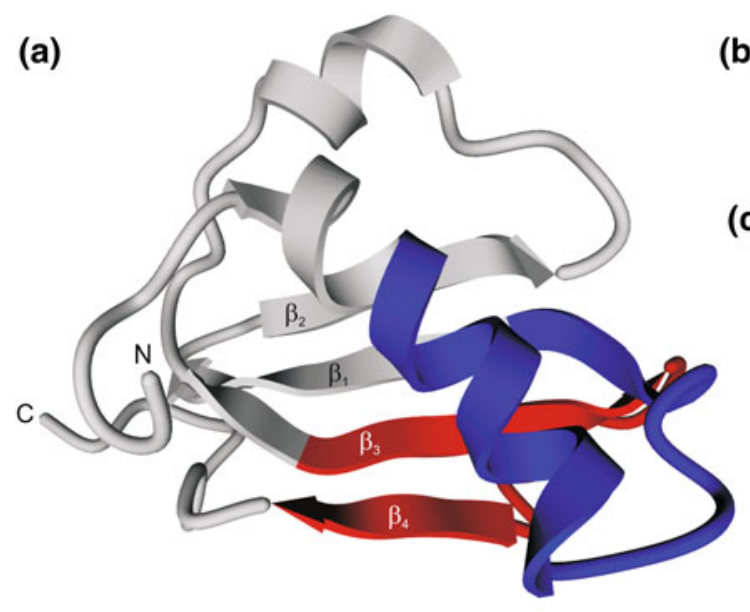

Fig. 1 Topology design of the CHOPS construct. a Cartoon representation of one of the NMR structures of CHIPS $_{31-121}$ (PDB ID code: 1XEE). The two regions interacting with the $\mathrm{C} 5 \mathrm{aR}$ are indicated: residues $43-61\left(\alpha\right.$-helix and $\left.\beta_{1}\right)$ and residues $95-111\left(\beta_{3}\right.$ and $\left.\beta_{4}\right)$. The $\mathrm{N}$ and $\mathrm{C}$ termini as well as the numbering of the $\beta$-strands are

sub-nanomolar affinity $\left(K_{\mathrm{d}} \approx 0.60 \mathrm{nM}\right.$; van Epps et al. 1993). Although under normal circumstances C5a-mediated C5aR activation is highly favorable, excessive levels of C5a can be deleterious to the host and have been related to numerous inflammatory and autoimmune diseases (e.g. rheumatoid arthritis, inflammatory bowel disease and reperfusion injury). Specific inhibition of C5aR activation is considered a promising strategy to treat such conditions (Allegretti et al. 2005). So far, the design and development of novel anti-inflammatory agents was primarily focussed on small organic compounds and short $\mathrm{C} 5 \mathrm{a}$ peptide analogs, which bind with high affinity to the $\mathrm{C} 5 \mathrm{aR}$ activation site (Allegretti et al. 2005; Monk et al. 2007). An alternative approach to inhibit C5aR activation was inspired by the discovery of the Chemotaxis Inhibitory Protein of Staphylococcus aureus abbreviated as CHIPS (Veldkamp et al. 2000). CHIPS is a 121-residue immune evasive protein excreted by Staphylococcus aureus bacteria in order to prevent host inflammatory responses triggered by formylated peptides and C5a. CHIPS binds to the formylated peptide receptor (FPR) and the C5aR with high affinity $\left(K_{\mathrm{d}}=35.4 \pm 7.7 \mathrm{nM}\right.$ and $K_{\mathrm{d}}=1.1 \pm 0.2 \mathrm{nM}$, respectively; Postma et al. 2004). Mutational studies revealed that the C5aR blocking activity of CHIPS is entirely conserved in a protein fragment lacking the first 30 residues. This truncated protein was designated CHIPS $_{31-121}$ and its structure was solved by Haas et al. (2005). CHIPS $_{31-121}$ has an entirely different folding topology compared to C5a and is composed of a single $\alpha$-helix packed onto a fourstranded anti-parallel $\beta$-sheet. This particular topology is present in several other $S$. aureus proteins with immune modulating properties (Haas et al. 2005).

In contrast to C5a, CHIPS binds exclusively to the C5aR $\mathrm{N}$ terminus (Postma et al. 2005). This part of the receptor is post-translationally modified by introduction of two sulfate groups on tyrosine residues at positions 11 and 14 (Farzan et al. 2001). Sulfation of these tyrosines appeared to be crucial for tight binding to CHIPS ${ }_{31-121}$ as was concluded from ITC binding studies using several sulfated and unsulfated mimics of the C5aR N terminus (Bunschoten et al. 2009; Ippel et al. 2009). The highest affinity for CHIPS $_{31-121}\left(K_{\mathrm{d}}=8.4 \pm 1.1 \mathrm{nM}\right)$ was observed for a peptide composed of residues $7-28$ of the $\mathrm{C} 5 \mathrm{aR}$ with both tyrosine residues sulfated (designated $\mathrm{C}_{5} \mathrm{aR}_{7-28} \mathrm{~S}_{2}$; Ippel et al. 2009). This peptide binds almost as strong to CHIPS as the native $\mathrm{C} 5 \mathrm{aR}$. This implies that all moieties essential for the interactions between CHIPS and the C5aR are present within this peptide mimic. The free $\mathrm{N}$ terminus of the C5aR is virtually unstructured, which is also the case for the short receptor mimics. Upon binding to CHIPS, residues $10-24$ of these $\mathrm{C} 5 \mathrm{aR}$ mimics adopt a well-defined conformation (PDB ID code: $2 \mathrm{~K} 3 \mathrm{U}$; Ippel et al. 2009). In the complex, residues $10-14$ and $19-24$ of $\mathrm{C}^{2} \mathrm{aR}_{7-28} \mathrm{~S}_{2}$ form two short stretches of $\beta$-strand, which are hydrogen bonded in an anti-parallel fashion to strand $\beta_{4}$ and residues 104-107 of CHIPS ${ }_{31-121}$, respectively. These two stretches are interconnected by a single turn comprising residues 15-18. Sulfated tyrosine 11 interacts mainly with residues in the $\alpha$-helix of CHIPS S1-121 $_{31}$, while sulfated tyrosine 14 is primarily accommodated by residues in the loop between 
the $\alpha$-helix and the first $\beta$-strand (residues 52-59; Fig. 1a). The sequence between residues T66 and Y94 of CHIPS ${ }_{31-121}$ does not contribute to interactions with the receptor, but is essential for its native structure (Ippel et al. 2009).

Despite its strong C5aR inhibitory potency, intact CHIPS itself is not amenable for use as an anti-inflammatory agent. Several immunogenic surface epitopes have been identified by Gustafsson et al. (2009). A recent study of Wright et al. (2007) showed the presence of anti-CHIPS antibodies in numerous serum samples of human donors. Therefore, administration of intact CHIPS protein can potentially lead to adverse immunogenic responses. Here, we describe the design, chemical synthesis, and analysis of a protein construct in which specific segments of CHIPS crucial for interactions with the C5aR have been incorporated while a number of non-interacting segments were omitted. We denote this protein construct with the acronym CHOPS, which stands for 'CHemotaxis inhibitory cOnstruct Protein of Staphylococcus aureus'. The ultimate goal is to obtain a CHOPS molecule, which is non-immunogenic, but has a high inhibitory potency for the C5aR.

\section{Materials and methods}

\section{Materials}

Peptide grade DiPEA, DCM, NMP, TFA, piperidine, and HPLC grade solvents were purchased from Biosolve B. V. (Valkenswaard, The Netherlands). Fmoc-protected amino acids were purchased from GL Biochem Ltd. (Shanghai, China). Side-chain protecting groups were chosen as: Boc for lysine, ${ }^{t} \mathrm{Bu}$ for aspartic acid, glutamic acid, serine, threonine, and tyrosine, Trt for asparagine and glutamine, and $\mathrm{Pbf}$ for arginine. Unless stated otherwise, chemicals were obtained from commercial sources and used without further purification.

\section{Compound analysis}

Analytical HPLC was performed using an automatic HPLC system (Shimadzu) with an analytical reversed-phase column and a UV detector operating at $214 \mathrm{~nm}$ with a flow rate of $0.75 \mathrm{~mL} / \mathrm{min}$. A Phenomenex Gemini C18 column $(110 \AA, 5 \mu \mathrm{m}, 250 \times 4.6 \mathrm{~mm})$ was used. TFA buffers were used (buffer A: $\mathrm{H}_{2} \mathrm{O}: \mathrm{MeOH}, 80: 20 \mathrm{v}: \mathrm{v}$; buffer B: $\mathrm{H}_{2} \mathrm{O}: \mathrm{MeOH}, 5: 95 \mathrm{v}: \mathrm{v}$, both containing 0.1\% TFA). Elution was effected with a linear gradient from $100 \%$ A to $100 \%$ B over $48 \mathrm{~min}$. Preparative HPLC was performed using an automatic Prep LCMS-QP8000 $\alpha$ HPLC system (Shimadzu) with a preparative reversed-phase column and a UV detector operating at $214 \mathrm{~nm}$ with a flow rate of $12.5 \mathrm{~mL} /$ min. A Reprosil-Pur C18-AQ column $(120 \AA$, $10 \mu \mathrm{m}$,
$250 \times 22 \mathrm{~mm}$ ) was used. TFA buffers were used (buffer A: $\mathrm{H}_{2} \mathrm{O}: \mathrm{MeOH}, 80: 20 \mathrm{v}$ : v; buffer $\mathrm{B}: \mathrm{H}_{2} \mathrm{O}: \mathrm{MeOH}, 5: 95 \mathrm{v}$ :v, both containing $0.1 \% \mathrm{TFA}$ ). Elution was effected with a linear gradient from $100 \%$ A to $100 \%$ B over 100 min. The peptides were characterized using electrospray mass spectrometry (ESI-MS), which was performed on a Thermo Finnigan LCQ DECA XP MAX ion trap mass spectrometer.

\section{Peptide synthesis}

CHOPS was synthesized on a Rink Amide PEG resin $(0.52 \mathrm{mmol} / \mathrm{g})$ (Matrix Innovation Inc., Montreal, Canada) on a $0.25 \mathrm{mmol}$ scale. The peptide was assembled using an automatic ABI 433A Peptide Synthesizer, equipped with a UV-monitoring system, which was used to monitor the Fmoc removal step, i.e., formation of the dibenzofulvenepiperidine adduct absorbing at $301 \mathrm{~nm}$. ABI FastMoc $0.25 \mathrm{mmol}$ protocols were applied, with the exception of a standard double coupling of $45 \mathrm{~min}$. The synthesis was carried out on $0.48 \mathrm{~g}$ resin. The resin was washed with DCM and NMP (five times). Subsequently, $1 \mathrm{mmol}$ of the appropriate amino acid was dissolved in NMP $(2 \mathrm{~mL})$, and HBTU/HOBt $(1 \mathrm{mmol}, 2.78 \mathrm{~mL}$ of $0.36 \mathrm{M})$ in NMP was added. To this mixture, DiPEA $(1 \mathrm{~mL}, 2 \mathrm{M})$ in NMP was added, and the activated amino acid was then transferred to the reaction vessel. After $45 \mathrm{~min}$, the reaction vessel was drained and the resin was washed with NMP (three times) followed by addition of another batch of pre-activated amino acid, which was allowed to couple for another $45 \mathrm{~min}$. Next, any of the remaining free amino groups were acetylated with an acetic anhydride capping solution (0.5 M Ac $\mathrm{Ac}_{2} \mathrm{O}, 0.125 \mathrm{M} \mathrm{DiPEA}$, and $0.015 \mathrm{M}$ HOBt in NMP) for 15 min. After capping the Fmoc protective group was removed from the $\mathrm{N}$ terminus by treatment with $20 \%$ piperidine solution in NMP twice ( 3 and $7.6 \mathrm{~min}$ ). The last coupling cycle was followed by removal of the Fmocgroup by a $20 \%$ piperidine solution, washing the resin with $\mathrm{NMP}$, and acetylation of the $\mathrm{N}$ terminus by treatment with the acetic anhydride capping solution for $15 \mathrm{~min}$. Finally, the resin was washed with NMP (five times) and DCM (six times), removed from the reaction vessel, washed with ether, and dried in vacuo over $\mathrm{P}_{2} \mathrm{O}_{5}$.

The anchored peptide obtained in this way was de-protected and cleaved from the solid support by treatment with TFA/ $\mathrm{H}_{2} \mathrm{O} /$ TIS $(95 / 2.5 / 2.5,25 \mathrm{~mL})$ for $2 \mathrm{~h}$ at room temperature. The mixture was filtered and the residue washed thoroughly with TFA (two times $10 \mathrm{~mL}$ ). The reaction mixture was concentrated in vacuo to a volume of approximately $10 \mathrm{~mL}$ and added dropwise to $90 \mathrm{~mL}$ $\mathrm{MTBE} / n$-hexane $(1 / 1 \mathrm{v} / \mathrm{v})$ solution. The precipitate was collected by centrifugation $(3,000 \mathrm{rpm}, 10 \mathrm{~min})$, the supernatant was decanted and the pellet was resuspended in MTBE/ $n$-hexane $(1 / 1 \mathrm{v} / \mathrm{v})(100 \mathrm{~mL})$ and centrifuged again. 
This procedure was repeated twice. Afterwards, the pellets were dissolved in $\mathrm{CH}_{3} \mathrm{CN} /$ water $(1 / 1 \mathrm{v} / \mathrm{v})$ (ca. $60 \mathrm{~mL}$ ) and lyophilized to give $595 \mathrm{mg}$ of the crude peptide as a white fluffy solid.

The crude peptide $(400 \mathrm{mg}$ ) was dissolved in $30 \mathrm{~mL}$ buffer A, $10 \mathrm{~mL}$ buffer $\mathrm{B}$ and purified by preparative HPLC (Reprosil-Pur C18-AQ, TFA buffers) in eight runs. Pure fractions were pooled and lyophilized to give $29 \mathrm{mg}$ of pure CHOPS. The CHOPS sample was characterized by analytical HPLC (Gemini C18, TFA buffers, $R_{\mathrm{t}}=36.4$ min, Purity $>98 \%$ ) (Supplementary Figure 1) and by ESI-MS (Supplementary Figure 2; calculated average mass $[\mathrm{M}+5 \mathrm{H}]^{5+}$ for $\mathrm{C}_{261} \mathrm{H}_{422} \mathrm{~N}_{70} \mathrm{O}_{74} \mathrm{~S}: 1,152.34$; found: 1,152.30).

The $\mathrm{C} 5 \mathrm{a}$ receptor mimic peptides $\mathrm{C}_{5} \mathrm{aR}_{7-28}$ and $\mathrm{C} \mathrm{aR}_{7-28} \mathrm{~S}_{2}$ were synthesized as has been described previously (Bunschoten et al. 2009).

\section{ITC experiments}

The binding affinities of the $\mathrm{C} 5 \mathrm{aR}$ mimics $\mathrm{C}_{5} \mathrm{aR}_{7-28}$ and $\mathrm{C} \mathrm{aR}_{7-28} \mathrm{~S}_{2}$ with CHOPS were measured using an $\mathrm{ITC}_{200}$ Microcalorimeter (MicroCal) operating at $283 \mathrm{~K}$. The measuring cell was filled with $208 \mu \mathrm{L}$ of a $0.19 \mathrm{mM}$ solution of CHOPS in a $20 \mathrm{mM}$ sodium phosphate buffer at $\mathrm{pH}$ 6.5. The concentration of CHOPS was determined by $\mathrm{OD}_{280}$ measurements. The syringe was loaded with $30 \mu \mathrm{L}$ of a $2.5 \mathrm{mM}$ solution of one of the C5aR-mimics in the same buffer system. After each incremental addition of the solution in the syringe, the integrated heat change due to binding was measured. The data were analyzed using the Microcal Origin software and fitted by non-linear regression analysis. Three independent experiments were carried out. The experimental errors were estimated by Monte Carlo simulations using the standard deviations of the individual experiments.

\section{NMR spectroscopy}

NMR samples of $\mathrm{C}_{5} \mathrm{aR}_{7-28}, \mathrm{C} \mathrm{aR}_{7-28} \mathrm{~S}_{2}$ and CHOPS were at concentrations of $0.8-1 \mathrm{mM}$ in $10 / 90 \%$ (v/v) $\mathrm{D}_{2} \mathrm{O} / \mathrm{H}_{2} \mathrm{O}$ sodium phosphate buffers $(20 \mathrm{mM}, \mathrm{pH}$ 6.5). Spectra were recorded at $288 \mathrm{~K}$ on a Varian INOVA 500 and a Bruker Avance $750 \mathrm{MHz}$ spectrometer equipped with an $\mathrm{HCN}$ triple-resonance pulsed field gradient probe. Sequential ${ }^{1} \mathrm{H}$ NMR assignments of CHOPS were accomplished using a combination of NOESY, TOCSY, and ${ }^{13} \mathrm{C}-\mathrm{HSQC}$ spectra.

\section{CD measurements}

CD spectra (190-260 nm) were recorded on an Olis RSM1000 spectrophotometer operating at $2 \mathrm{~nm}$ spectral resolution (slit size $1.24 \mathrm{~mm}$ ). Samples of CHIPS $_{31-121}$
$(43 \mu \mathrm{M})$ in $20 \mathrm{mM}$ sodium phosphate buffer (pH 6.5), CHOPS $(50 \mu \mathrm{M}), \mathrm{C}^{2} \mathrm{aR}_{7-28}$ and $\mathrm{C} \mathrm{aR}_{7-28} \mathrm{~S}_{2}(50 \mu \mathrm{M})$ in $10 \mathrm{mM}$ sodium phosphate buffer ( $\mathrm{pH}$ 7.4) were measured at $298 \mathrm{~K}$ using a $0.5 \mathrm{~mm}$ cuvette. To gain a satisfactory $\mathrm{S} / \mathrm{N}$ ratio five scans were summed, with data points averaged by three-point triangular smoothing.

\section{Results and discussion}

\section{Design of CHOPS}

The Staphylococcal protein CHIPS is one of the most potent inhibitors of C5a-induced inflammatory responses presently known. In contrast to the numerous agents developed to interact directly with the C5aR activation site located inside the receptor core (Proctor et al. 2006; Chen et al. 2010), CHIPS blocks activation by C5a by binding with high affinity to the flexible extra-cellular N-terminal portion of the C5aR (Postma et al. 2005). The interaction surface of CHIPS ${ }_{31-121}$ with the C5aR comprises $\sim 20 \%$ of its solvent accessible surface and is not confined to a limited region of the protein. The interactions between CHIPS and the C5aR involve a substantial number of nonsequential amino acids optimally positioned in the inhibitory protein to provide tight binding. A successful mimic of CHIPS should not only include the amino acid residues (or mimics of these) crucial for C5aR binding, but also the amino acids responsible for the proper spatial arrangement dictated by the CHIPS folding topology. Our first approach to build such a structure is to leave out a limited number of residues which do not interact directly with the C5aR, but with the intention to leave the structural integrity of CHIPS $_{31-121}$ intact. NMR titration studies revealed that two regions of CHIPS 31-121 show relatively large perturbations in the backbone and C $\beta$ chemical shifts (Ippel et al. 2009): the first region includes residues 43-61, which comprises part of the $\alpha$-helix and the subsequent loop connecting strand $\beta_{1}$ (Fig. 1a). The second region is composed of residues 95-111 and comprises strands $\beta_{3}$ and $\beta_{4}$ of CHIPS $_{31-121}$. The non-interacting portion of CHIPS $_{31-121}$ comprises strand $\beta_{2}$ and the long loop connecting $\beta_{2}$ with $\beta_{3}$ (Fig. 1a). This portion could potentially be left out by directly connecting strand $\beta_{1}$ with $\beta_{3}$ via a tight turn. Inspection of the NMR structural models of CHIPS $_{31-121}$ reveals that residue $\mathrm{L} 65$ at the end of strand $\beta_{1}$ and residue K95 at the start of strand $\beta_{3}$ are proximal and offer an excellent opportunity to link the two fragments interacting with the $\mathrm{C} 5 \mathrm{aR}$ together to form one short, contiguous sequence. Several $\beta$-hairpin inducing sequences have been described and reviewed in the literature (Blanco et al. 1998; Stotz and Topp 2004). One of the smallest peptide fragments, which induces a $\beta$-turn and facilitates the 
formation of an anti-parallel $\beta$-sheet, is the dipeptide D-Pro-Gly (Haque and Gellman 1997). This fragment was chosen to link the N-and C-terminal segments of CHIPS, which interact with the $\mathrm{C} 5 \mathrm{aR}$, together. These segments were chosen to comprise the complete elements of secondary structure as present in native CHIPS (i.e. the $\alpha$-helix and $\beta$-strands $\beta_{1}, \beta_{3}$, and $\beta_{4}$ ) in order to pursue structural integrity. The resulting construct consisted of the CHIPS amino acid sequences T36-L65 and K95-G112 interconnected by D-Pro-Gly (Fig. 1b). A number of residues suggested to be part of discontinuous immunogenic epitopes by Gustafsson et al. (2009) are not present in this construct (designated CHOPS). A model representation of CHOPS based on the structure of native CHIPS $_{31-121}$ is presented in Fig. 1c.

\section{Affinity of CHOPS for the C5aR $\mathrm{N}$ terminus}

The affinity of the CHOPS fragment for the C5aR was determined using isothermal titration calorimetry (ITC). We synthesized two peptide mimics of the C5aR $\mathrm{N}$ terminus: unsulfated peptide $\mathrm{C}_{5} \mathrm{aR}_{7-28}$ representing residues 7-28 of the $\mathrm{C} 5 \mathrm{aR}$ and peptide $\mathrm{C}_{5} \mathrm{aR}_{7-28} \mathrm{~S}_{2}$, the same sequence with tyrosine residues 11 and $14 O$-sulfated. We titrated a solution of CHOPS with these peptides and recorded the subsequent heat exchange upon formation of the complex. Two typical ITC experiments are shown in Supplementary Figure 3. Clearly, titration of the doubly sulfated peptide $\mathrm{C}_{5} \mathrm{aR}_{7-28} \mathrm{~S}_{2}$ to CHOPS resulted in a substantial exothermic effect (Supplementary Figure 3a) while no significant response was detected in the ITC experiment with the unsulfated peptide $\mathrm{C}_{5} \mathrm{aR}_{7-28}$ (Supplementary Figure $3 \mathrm{~b}$ ). Gratifyingly, the affinity of CHOPS for $\mathrm{C}_{5} \mathrm{aR}_{7-28} \mathrm{~S}_{2}$ was in the micromolar range $\left(K_{\mathrm{d}}=3.6 \pm 0.2 \mu \mathrm{M} ; n=3\right)$. The complete thermodynamic analysis of these ITC data plus the comparison with previous ITC studies of CHIPS $_{31-121}$ and C5a peptide mimics is compiled in Supplementary Table 1.

\section{NMR spectroscopy}

Previous NMR studies revealed that the synthetic peptides $\mathrm{C}_{5} \mathrm{aR}_{7-28}$ and $\mathrm{C}_{5} \mathrm{aR}_{7-28} \mathrm{~S}_{2}$, which mimic the N-terminal portion of the C5aR, were very flexible in solution and did not have detectable propensity for any preferred secondary structure. Although there is no detailed structure available for the intact $\mathrm{C} 5 \mathrm{aR}$, it is expected that its free extra-cellular $\mathrm{N}$ terminus (residues 1-35) is unstructured as well. The protein CHIPS $_{31-121}$ does adopt a well-defined conformation with flexible regions at the termini and some disorder in the loop region between the $\alpha$-helix and strand $\beta_{1}$ (Haas et al. 2005). As could be inferred from ${ }^{15} \mathrm{~N}$ relaxation studies this particular loop region adopts an ordered conformation in the complex with $\mathrm{C}_{5} \mathrm{aR}_{7-28} \mathrm{~S}_{2}$ (Ippel et al.
2009). NMR spectra of the free CHOPS construct appear to be typical for a largely unstructured polypeptide chain (Supplementary Figure 4a). 2D NOE spectra of free CHOPS contain predominantly sequential NOEs, but a few long-range contacts could be identified. These nonsequential cross-peaks are indicative for an anti-parallel orientation of strands $\beta_{1}$ and $\beta_{3}$, which are bridged by the $\beta$-hairpin inducing D-Pro-Gly sequence (Fig. 2).

Titration of CHOPS with the unsulfated receptor mimic $\mathrm{C} \mathrm{aR}_{7-28}$ did not result in any changes in the ${ }^{1} \mathrm{H}$-spectrum of the latter. In contrast, titration of CHOPS with the sulfated receptor mimic $\mathrm{C}_{5} \mathrm{aR}_{7-28} \mathrm{~S}_{2}$ resulted in increased dispersion of resonance lines, which is characteristic for non-random coil behavior (Supplementary Figure 4b). The complex between CHOPS and $\mathrm{C}_{5} \mathrm{aR}_{7-28} \mathrm{~S}_{2}$ is still flexible and the ${ }^{1} \mathrm{H}$-spectra show a high degree of overlap. Nevertheless, we could assign some of the NMR signals as indicated in Supplementary Figure $4 \mathrm{~b}$. These new signals are at comparable positions as in spectra of the complex between $\mathrm{CHIPS}_{31-121}$ and $\mathrm{C}_{5} \mathrm{aR}_{7-28} \mathrm{~S}_{2}$, and indicative for the formation of native-like structure. Similar features were observed in ${ }^{1} \mathrm{H}-{ }^{13} \mathrm{C}$ HSQC spectra upon titration of $\mathrm{C} \mathrm{aR}_{7-28} \mathrm{~S}_{2}$ to CHOPS (Fig. 3).

The NOESY spectra of the CHOPS: $\mathrm{C}_{5} \mathrm{aR}_{7-28} \mathrm{~S}_{2}$ complex suffer from severe overlap, but still a limited number of long-range intra-molecular and inter-molecular NOE cross-peaks could be assigned. Inter-molecular NOEs were identified between the aromatic side-chain protons of sulfated tyrosine sY14 of $\mathrm{C}_{5} \mathrm{aR}_{7-28} \mathrm{~S}_{2}$ and the side-chains of T53 (Fig. 4a) and Y108 (Fig. 4c) of CHOPS. H13 of $\mathrm{C} \mathrm{aR}_{7-28} \mathrm{~S}_{2}$ has an NOE contact with V109 of CHOPS (Fig. 4b). Intra-molecular NOEs were identified between T53 and L49 and between Y97 and V109 (Fig. 4a). Similar peaks were observed in NOESY spectra of the complex between $\mathrm{CHIPS}_{31-121}$ and $\mathrm{C} \mathrm{aR}_{7-28} \mathrm{~S}_{2}$. The position of these residues in the NMR structure of the $\mathrm{CHIPS}_{31-121}$ : $\mathrm{C} \mathrm{aR}_{7-28} \mathrm{~S}_{2}$ complex is indicated in Fig. $4 \mathrm{~d}$, e.

\section{CD spectroscopy}

The presence of residual structure in the C5aR mimics and CHOPS was also monitored by CD spectroscopy. The CD spectra of the C5a-receptor mimics $\mathrm{C}_{5} \mathrm{aR}_{7-28}$ and $\mathrm{C} \mathrm{aR}_{7-28} \mathrm{~S}_{2}$, and CHOPS show no structural features apart from a shallow minimum at $200 \mathrm{~nm}$ (Fig. 5). The CD spectrum of free $\mathrm{CHIPS}_{31-121}$ comprises a large positive signal around $190 \mathrm{~nm}$ and a minimum around $205 \mathrm{~nm}$ (Fig. 5). This spectrum does not change significantly upon binding of $\mathrm{C} \mathrm{aR}_{7-28} \mathrm{~S}_{2}$ (data not shown). Titration of CHOPS with a stoichiometric amount of unsulfated receptor mimic $\mathrm{C}_{5} \mathrm{aR}_{7-28}$ resulted in an increase of the $\mathrm{CD}$ signal, although the shape of the spectrum did not change (Fig. 5a). Stoichiometric titration of CHOPS with sulfated 
Fig. 2 Section of the NOESY spectrum of free CHOPS in solution. Several cross-peak assignments are shown indicative for the presence of a $\beta$-hairpin comprising strands $\beta_{1}$ and $\beta_{3}$

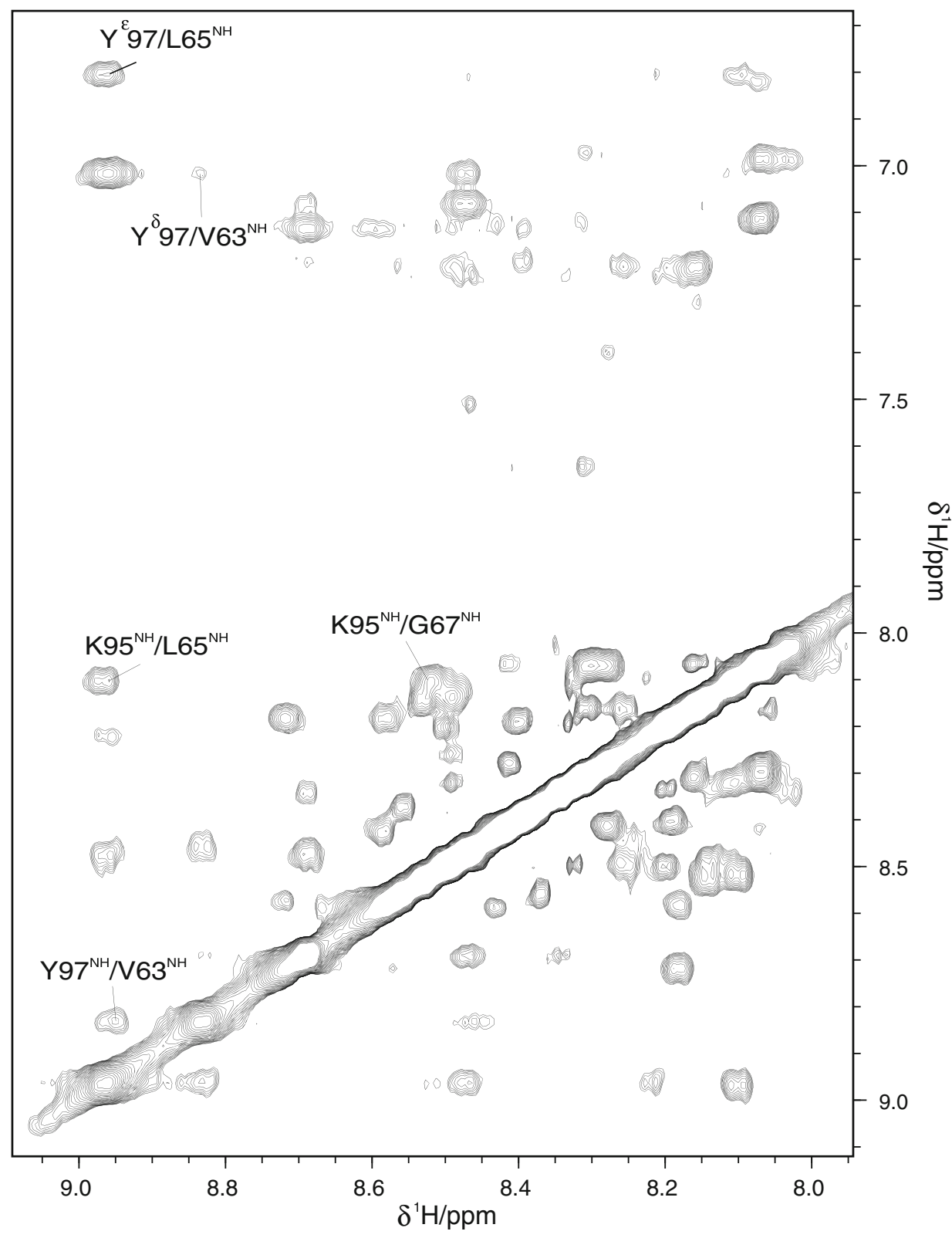

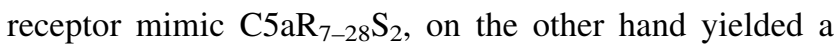
clear change of the $\mathrm{CD}$ spectrum: an increase in the signal around $190 \mathrm{~nm}$ and a shift of the minimum from 200 to $205 \mathrm{~nm}$ (Fig. 5b). These changes shift the appearance of the $\mathrm{CD}$ spectrum towards that of $\mathrm{CHIPS}_{31-121}$ although at lower intensities.

In this study we aimed to create a shorter version of the immune evasive protein CHIPS based on the NMR structure of the complex between CHIPS $\mathrm{S1-121}_{31}$ and $\mathrm{C} \mathrm{aR}_{7-28} \mathrm{~S}_{2}$. The construct we designed (CHOPS) comprises all portions of CHIPS $_{31-121}$ important in the interaction with the C5aR. Portions outside the binding region including strand $\beta_{2}$ and the connecting loop between $\beta_{2}$ and $\beta_{3}$ were discarded. This was accomplished by coupling strand $\beta_{1}$ and $\beta_{3}$ together via a D-Pro-Gly linker segment. The resulting 50-residue long peptide appeared to be largely unfolded apart from some residual structure around the $\beta$-hairpin inducing D-Pro-Gly linker sequence. ITC studies revealed that CHOPS binds to the doubly sulfated C5a-receptor

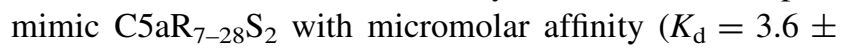
$0.2 \mu \mathrm{M}$ ). Although the affinity of $\mathrm{C}^{2} \mathrm{aR}_{7-28} \mathrm{~S}_{2}$ to CHOPS is three orders of magnitude lower compared to binding to CHIPS $_{31-121}\left(K_{\mathrm{d}}=8.4 \pm 1.2 \mathrm{nM}\right.$; Ippel et al. 2009), this is a very promising result for a first lead compound. No detectable affinity of CHOPS was observed in the ITC measurements using the unsulfated mimic $\mathrm{C}_{5} \mathrm{aR}_{7-28}$. This is consistent with previous measurements of $\mathrm{CHIPS}_{31-121}$ and $\mathrm{C}_{5} \mathrm{aR}_{7-28}$, which revealed that the absence of the two sulfate moieties results in an almost 400-fold decrease in affinity. 
Fig. $3{ }^{1} \mathrm{H}_{-}{ }^{13} \mathrm{C}$ HSQC spectra of CHOPS. a Methyl group region of the ${ }^{1} \mathrm{H}-{ }^{13} \mathrm{C}$ HSQC spectrum free CHOPS.

b Similar spectrum of CHOPS in complex with receptor mimic $\mathrm{C}_{5} \mathrm{RR}_{7-28} \mathrm{~S}_{2}$. The assignments are indicated. Peaks originating from $\mathrm{C}_{5} \mathrm{aR}_{7-28} \mathrm{~S}_{2}$ are shown in italic font
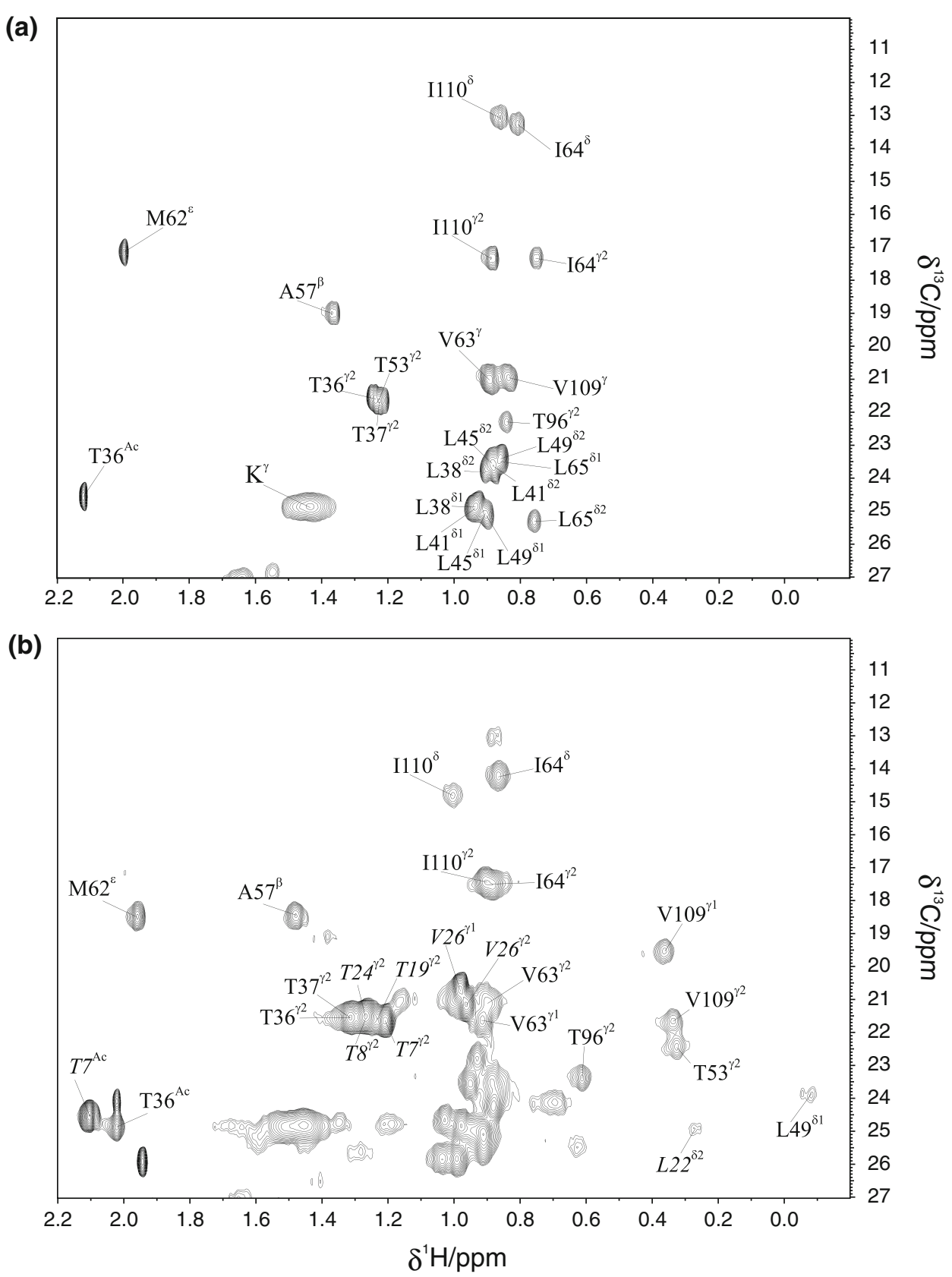

NMR spectroscopy confirmed the results obtained by ITC. Titration of CHOPS with unsulfated receptor mimic $\mathrm{C} \mathrm{aR}_{7-28}$ resulted in the sum of its constituent ${ }^{1} \mathrm{H}$-spectra, while titration of doubly sulfated peptide $\mathrm{C}_{5} \mathrm{aR}_{7-28} \mathrm{~S}_{2}$ yielded a completely different ${ }^{1} \mathrm{H}$-spectrum with signals shifted from their random coil position. The latter is indicative for the formation of defined structural elements. The NMR titration experiments using $\mathrm{C}_{5} \mathrm{aR}_{7-28} \mathrm{~S}_{2}$ showed binding in a fast-exchange regime, compatible with the observed micromolar affinity by ITC (Cavanagh et al. 2007). Several characteristic features observed in spectra of the $\mathrm{CHIPS}_{31-121}: \mathrm{C} \mathrm{aR}_{7-28} \mathrm{~S}_{2}$ complex were also present in spectra of CHOPS:C5aR $\mathrm{C}_{7-28} \mathrm{~S}_{2}$. Specific resonances of residues L49, T53, T96, Y97, Y108, V109 and N111 have chemical shifts comparable with their counterparts in the $\mathrm{CHIPS}_{31-121}: \mathrm{C} \mathrm{aR}_{7-28} \mathrm{~S}_{2}$ complex. We also observed NOE cross-peaks between residues $s Y 14$, T53, L49, and Y108 and between residues H13, V109, and Y97 in NOESY spectra of CHOPS:C5aR $\mathrm{aR}_{7-28} \mathrm{~S}_{2}$. These peaks are reminiscent of NOE contacts observed in spectra of the complex between CHIPS $_{31-121}$ and $\mathrm{C}_{5} \mathrm{aR}_{7-28} \mathrm{~S}_{2}$ and reveal that CHOPS, in the presence of sulfated peptide $\mathrm{C}_{5} \mathrm{aR}_{7-28} \mathrm{~S}_{2}$, adopts similar structures as native CHIPS $_{31-121}$. 
(a)

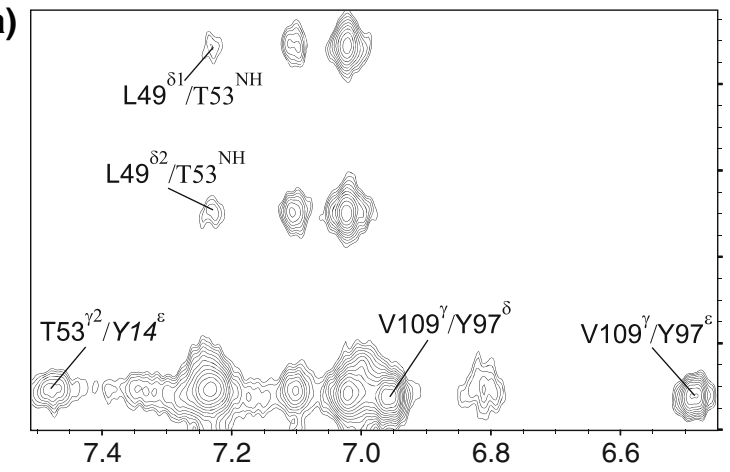

(b)

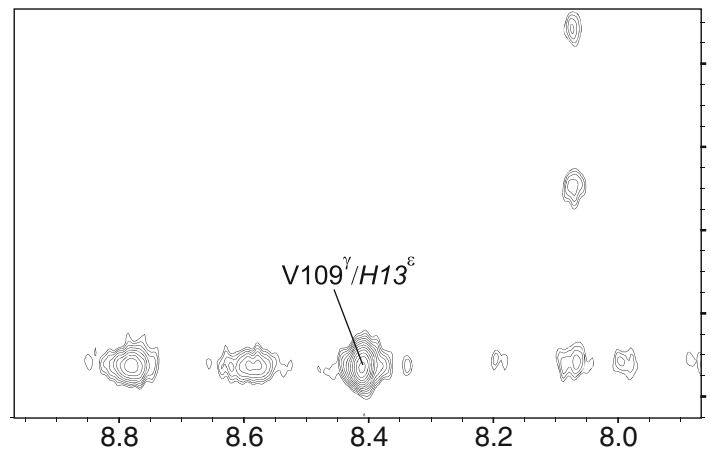

(c)

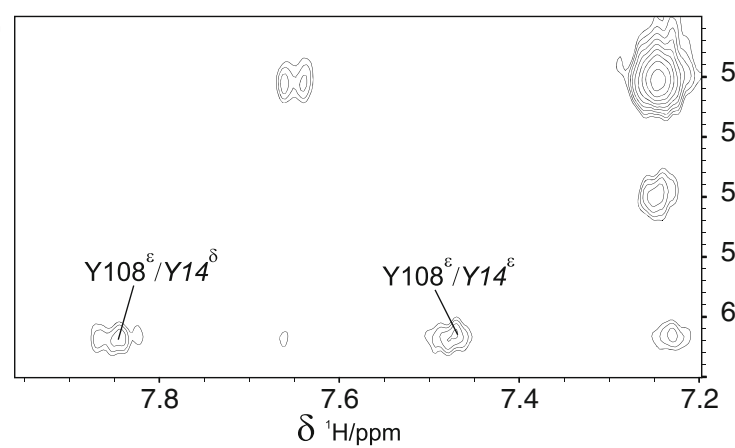

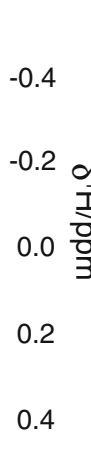

$-0.4$

(d)

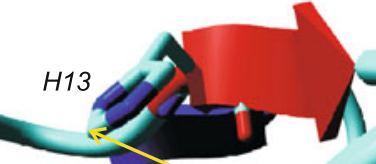

$\mathrm{C} \mathrm{aR}_{7-28} \mathrm{~S}_{2}$
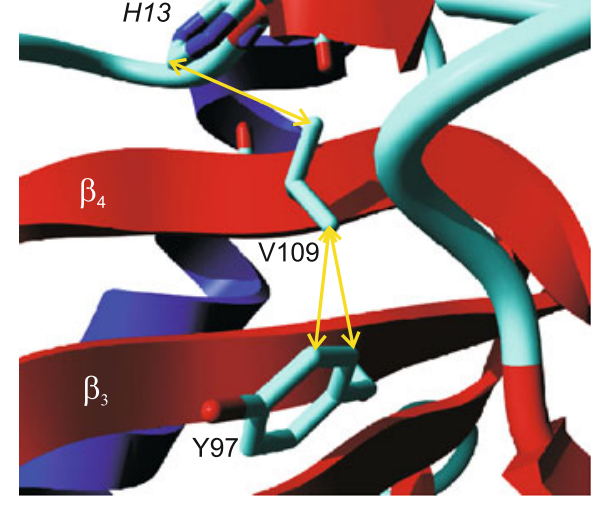

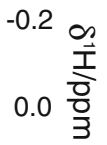

(e)

0.2

0.4

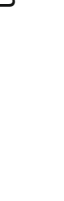

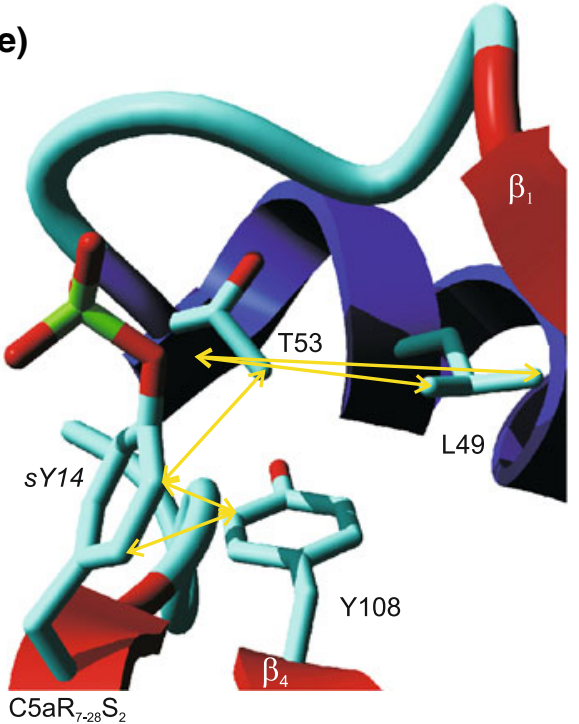

Fig. 4 Observed cross-peaks in the NOESY spectrum of the CHOPS:C5aR ${ }_{7-28} \mathrm{~S}_{2}$ complex in relation to structural features of the

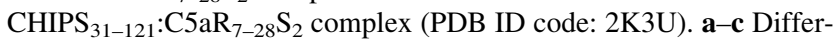
ent sections of the NOESY spectrum recorded at $288 \mathrm{~K}$ of a $1: 1$ mixture of CHOPS and $\mathrm{C} \mathrm{aR}_{7-28} \mathrm{~S}_{2}$. Identified long-range intramolecular and inter-molecular NOE cross-peaks are indicated

The structural characteristics of CHOPS, either free in solution or in complex with the C5aR mimics, were also studied by $\mathrm{CD}$ spectroscopy. The spectra of the separate peptides (CHOPS, $\mathrm{C}_{5} \mathrm{aR}_{7-28}$ or $\mathrm{C}_{5} \mathrm{aR}_{7-28} \mathrm{~S}_{2}$ ) did not show any significant absorption apart from a shallow minimum around $200 \mathrm{~nm}$. Titration of CHOPS with receptor mimic $\mathrm{C}_{5} \mathrm{aR}_{7-28}$ increased the amount of absorption, but not the position of its minimum. Titration of CHOPS with the doubly sulfated receptor mimic $\mathrm{C}_{5} \mathrm{aR}_{7-28} \mathrm{~S}_{2}$ caused an increase in absorption around $190 \mathrm{~nm}$ as well as a shift of the absorption minimum from 200 to $205 \mathrm{~nm}$. Although the maximum and minimum intensities are smaller, the overall shape of the CD spectrum of the CHOPS:C5aR $\mathrm{aR}_{7-28} \mathrm{~S}_{2}$ complex resembles that of native $\mathrm{CHIPS}_{31-121}$. (normal fonts for residues belonging to CHOPS and italic fonts for residues belonging to $\mathrm{C}_{5} \mathrm{aR}_{7-28} \mathrm{~S}_{2}$ ). d-e Cartoon representation of the structure of the CHIPS ${ }_{31-121}: \mathrm{C}^{2} \mathrm{aR}_{7-28} \mathrm{~S}_{2}$ complex. The side-chains of the residues identified in $\mathbf{a}-\mathbf{c}$ are shown in stick representation. NOE cross-peaks observed in $\mathbf{a}-\mathbf{c}$ are indicated by arrows in the structure

\section{Conclusions}

We have designed and synthesized a significantly reducedsize mimic of the protein CHIPS, which we coined CHOPS. This construct has a binding affinity of $3.6 \mu \mathrm{M}$ with respect to the sulfated receptor mimic $\mathrm{C}_{5} \mathrm{aR}_{7-28} \mathrm{~S}_{2}$, but no affinity for the unsulfated receptor mimic $\mathrm{C}_{5} \mathrm{aR}_{7-28}$. We conclude, based on NMR and CD studies, that CHOPS adopts structures comparable with native CHIPS $_{31-121}$ upon binding of $\mathrm{C}_{5} \mathrm{aR}_{7-28} \mathrm{~S}_{2}$. The CHOPS:C5aR $5 \mathrm{aR}_{728} \mathrm{~S}_{2}$ complex is, however, still flexible. We expect that improved affinity can be achieved by introduction of more rigid moieties, which will force this mimic more into the structure of native CHIPS. 

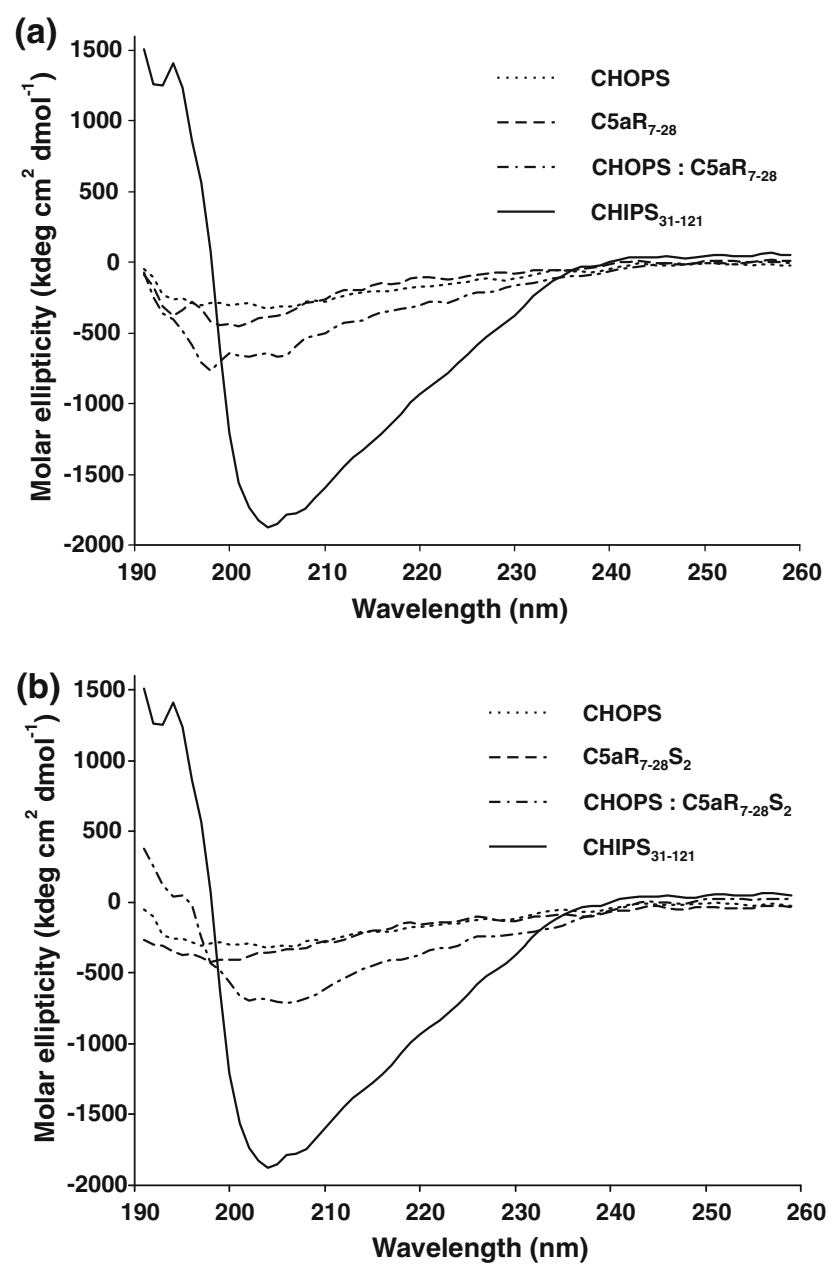

Fig. 5 Circular dichroism spectra (CD) of CHOPS, CHIPS $_{31-121}$ and C5aR mimics. a CD spectra of CHOPS, C5aR $7-28$, CHOPS:C5aR ${ }_{7-28}$, and $\mathrm{CHIPS}_{31-121}$. b CD spectra of CHOPS, C5aR $\mathrm{aR}_{7-28} \mathrm{~S}_{2}$, CHOPS: $\mathrm{C} \mathrm{aR}_{7-28} \mathrm{~S}_{2}$, and $\mathrm{CHIPS}_{31-121}$

Acknowledgments This work was supported in part by the Dutch Technology Foundation STW, Applied Science Division of NWO, and the Technology Program of the Ministry of Economic Affairs (UKG.06609).

Open Access This article is distributed under the terms of the Creative Commons Attribution Noncommercial License which permits any noncommercial use, distribution, and reproduction in any medium, provided the original author(s) and source are credited.

\section{References}

Allegretti M, Moriconi A, Beccari AR, Di Bitondo R, Bizzarri C, Bertini R, Colotta F (2005) Targeting C5a: recent advances in drug discovery. Curr Med Chem 12:217-236

Blanco F, Ramirez-Alvarado M, Serrano L (1998) Formation and stability of beta-hairpin structures in polypeptides. Curr Opin Struct Biol 8:107-111
Bunschoten A, Kruijtzer JAW, Ippel JH, de Haas CJC, van Strijp JAG, Kemmink J, Liskamp RMJ (2009) A general sequence independent solid phase method for the site specific synthesis of multiple sulfated-tyrosine containing peptides. Chem Commun 2999-3001

Cavanagh J, Fairbrother WJ, Palmer AG, Rance M, Skelton NJ (2007) Protein NMR spectroscopy: principles and practice, 2nd edn. Elsevier Academic Press, San Diego

Chen ZG, Zhang XL, Gonnella NC, Pellas TC, Boyar WC, Ni F (1998) Residues 21-30 within the extracellular N-terminal region of the $\mathrm{C} 5 \mathrm{a}$ receptor represent a binding do main for the C5a anaphylatoxin. J Biol Chem 273:10411-10419

Chen JJ, Cole DC, Ciszewski G, Crouse K, Ellingboe JW, Nowak P, Tawa GJ, Berstein G, Li W (2010) Identification of a new class of small molecule C5a receptor antagonists. Bioorg Med Chem Lett 20:662-664

Farzan M, Schnitzler CE, Vasilieva N, Leung D, Kuhn J, Gerard C, Gerard NP, Choe H (2001) Sulfated tyrosines contribute to the formation of the C5a docking site of the human C5a anaphylatoxin receptor. J Exp Med 193:1059-1065

Gerber BO, Meng EC, Dotsch V, Baranski TJ, Bourne HR (2001) An activation switch in the ligand binding pocket of the C5a receptor. J Biol Chem 276:3394-3400

Guo RF, Ward PA (2005) Role of C5A in inflammatory responses. Annu Rev Immunol 23:821-852

Gustafsson E, Haas PJ, Walse B, Hijnen M, Furebring C, Ohlin M, van Strijp JAG, van Kessel KPM (2009) Identification of conformational epitopes for human IgG on Chemotaxis inhibitory protein of Staphylococcus aureus. BMC Immunol 10:13

Haas PJ, de Haas CJC, Poppelier MJJC, van Kessel KPM, van Strijp JAG, Dijkstra K, Scheek RM, Fan H, Kruijtzer JAW, Liskamp RMJ, Kemmink J (2005) The structure of the C5a receptorblocking domain of chemotaxis inhibitory protein of Staphylococcus aureus is related to a group of immune evasive molecules. J Mol Biol 353:859-872

Haque TS, Gellman SH (1997) Insights on beta-hairpin stability in aqueous solution from peptides with enforced type $\mathrm{I}^{\prime}$ and type $\mathrm{II}^{\prime}$ beta-turns. J Am Chem Soc 119:2303-2304

Ippel JH, De Haas CJC, Bunschoten A, van Strijp JAG, Kruijtzer JAW, Liskamp RMJ, Kemmink J (2009) Structure of the tyrosine-sulfated C5a-receptor $\mathrm{N}$-terminus in complex with chemotaxis inhibitory protein of Staphylococcus aureus. J Biol Chem 284:12363-12372

Lee H, Whitfeld PL, Mackay CR (2008) Receptors for complement C5a. The importance of $\mathrm{C} 5 \mathrm{aR}$ and the enigmatic role of C5L2. Immunol. Cell Biol 86:153-160

Monk PN, Scola A, Madala PK, Fairlie DP (2007) Function, structure and therapeutic potential of complement $\mathrm{C} 5 \mathrm{a}$ receptors. $\mathrm{Br} \mathrm{J}$ Pharmacol 152:429-448

Postma B, Poppelier MJ, van Galen JC, Prossnitz ER, van Strijp JAG, de Haas CJC, van Kessel KPM (2004) Chemotaxis inhibitory protein of Staphylococcus aureus binds specifically to the C5a and formylated peptide receptor. J Immunol 172:6994-7001

Postma B, Kleibeuker W, Poppelier MJJG, Boonstra M, Van Kessel KPM, Van Strijp JAG, de Haas CJC (2005) Residues 10-18 within the $\mathrm{C} 5 \mathrm{a}$ receptor $\mathrm{N}$-terminus compose a binding domain for chemotaxis inhibitory protein of Staphylococcus aureus. J Biol Chem 280:2020-2027

Proctor LM, Woodruff TM, Taylor SM (2006) Recent developments in C5/C5a inhibitors. Expert Opin Ther Pat 16:445-458

Stotz CE, Topp EM (2004) Applications of model beta-hairpin peptides. J Pharm Sci 93:2881-2894

van Epps DE, Simpson SJ, Johnson R (1993) Relationship of C5a receptor modulation to the functional responsiveness of human polymorphonuclear leukocytes to C5a. J Immunol 150:246-252 
Veldkamp KE, Heezius HCJM, Verhoef J, van Strijp JAG, van Kessel KPM (2000) Modulation of neutrophil chemokine receptors by Staphylococcus aureus supernate. Infect Immun 68:5908-5913

Wright AJ, Higginbottom A, Philippe D, Upadhyay A, Bagby S, Read RC, Monk PN, Partridge LJ (2007) Characterisation of receptor binding by the chemotaxis inhibitory protein of Staphylococcus aureus and the effects of the host immune response. Mol Immunol 44:2507-2517 